\title{
CHARACTERIZATION OF UREA ANALYTE SOLUTION AND ELECTROLYTE SOLUTION USING NON-IMMOBILIZED ELECTRODE INDICATORS AND PVA-ENZYME COATED PVC-KTPCIPB IMMOBILIZATION
}

\author{
A. Hakim $S^{1,3, \bigotimes}$, M. Situmorang ${ }^{2}$, K. Sebayang ${ }^{3}$, T. Sembiring ${ }^{3}$, K. \\ Tarigan $^{3}$, S. Mihardi ${ }^{1}$, N. M. Noor ${ }^{3}$ and J. Elnovreny ${ }^{4}$ \\ ${ }^{1}$ Department of Physics, Universitas Negeri Medan, Jl. Willem Iskandar Pasar V-20221, \\ Medan, Indonesia \\ ${ }^{2}$ Department of Chemistry, Universitas Negeri Medan, Jl. Willem Iskandar Pasar V-20221, \\ Medan, Indonesia \\ ${ }^{3}$ Department of Physics, Universitas Sumatera Utara, Jl. Bioteknologi No. 1-20155, \\ Medan, Indonesia \\ ${ }^{4}$ Department of Physics, Universitas Potensi Utama, Jl. KL Yos Sudarso-20241, \\ Medan, Indonesia \\ \Corresponding Author: abdhakims@unimed.ac.id
}

\begin{abstract}
Electrolyte solutions used in potentiometric cells from ion-selective electrode (ISE) sensors urea contribute to a good enzymatic reaction. This study aims to obtain electrolyte solutions that have the best response to ISE on the electrode modification membrane electrode $35 \mathrm{mg}$ PVA-enzyme coating $35 \mathrm{mg}$ PVC-500 mg KTpCIPB. Solution analysis begins with the characterization of ISE electrode membranes using UV-vis, SEM-EDX, and XRD, the best results on electrode membranes are used as ISE. Analyzing the solution sequentially is a phosphate buffer solution, $\mathrm{KCl}$ phosphate buffer solution and phosphate buffer $\mathrm{KCl}$ injection with urea using a potentiometer, power lab, and computer to see the solution response. Based on the results of the computer response obtained a phosphate buffer solution pH 5.5, $0.001 \mathrm{M}, 0.001 \mathrm{M} \mathrm{KCl}$, and $0.001 \mathrm{M}$ urea.
\end{abstract}

Keywords: Solution, Characterization of ISE, Electrode Indicator, PVA-enzyme Coated PVC-KTpCIPB.

RASĀYAN J. Chem., Vol. 14, No.2, 2021

\section{INTRODUCTION}

A membrane is a semipermeable thin film-shaped porous media that functions to separate particles in a solution system. Analytes are chemicals that are tested on water, air, or blood samples. For example, if the analyte is urea, laboratory tests will determine the amount of urea in the sample. The membrane allows the analyte analyzed to diffuse and come into direct contact with the indicator electrodes located in the electrolyte solution. Analytic diffusion is important because it has to go through the membrane, besides that the membrane removes the redox-active substances that interfere so as not to be trapped in the sample.

Biosensors are defined as integrated devices that can provide specific quantitative or semi-quantitative analytic information. Biosensors usually consist of analytes in the sample, a bioreceptor (biorecognition element), transducer and signal amplification and analysis circuit.

Biosensors are used as analytical tools that respond to certain concentrations of chemicals in biological samples. Biosensors, using biological components as catalysts in electrodes. The analyte is usually detected through physical binding or chemical reactions that occur at the electrodes. Enzymes are biocatalysts that are useful for increasing reaction rates without substantial consumption during reactions. Enzymes have been widely used in applications because of their high specificity, selectivity, biocompatible properties, and when immobilized on the electrode surface resulting in higher current 
RASĀYAN J. Chem.

Vol. 14 | No. 2 |1356-1368| April - June | 2021

density and power. They are precise and show high selectivity. Effective cycles at low current densities of $0.1 \mathrm{~mA} \mathrm{~cm}{ }^{-2}$ to 5,000 cycles from periodic voltage plots containing electrolytes. ${ }^{1}$ It can be seen in Fig.1(a) in the $0.001 \mathrm{M}$ phosphate buffer solution (PBS) pH 5.5 urea injection and 1 (b) in the $0.001 \mathrm{M}$ solution phosphate buffer $\mathrm{pH} 5.5 \mathrm{KCl}$ urea injection there are differences in charge/discharge cycles so that there are more periodic stress cycles in Fig. $-1(\mathrm{~b}),{ }^{2}$ there is only signal attenuation ${ }^{3}$ when adding $\mathrm{KCl}$, an interactive redox-probing approach to access redox-based chemical information and convert this information into electricity by a signal processing method. ${ }^{3}$
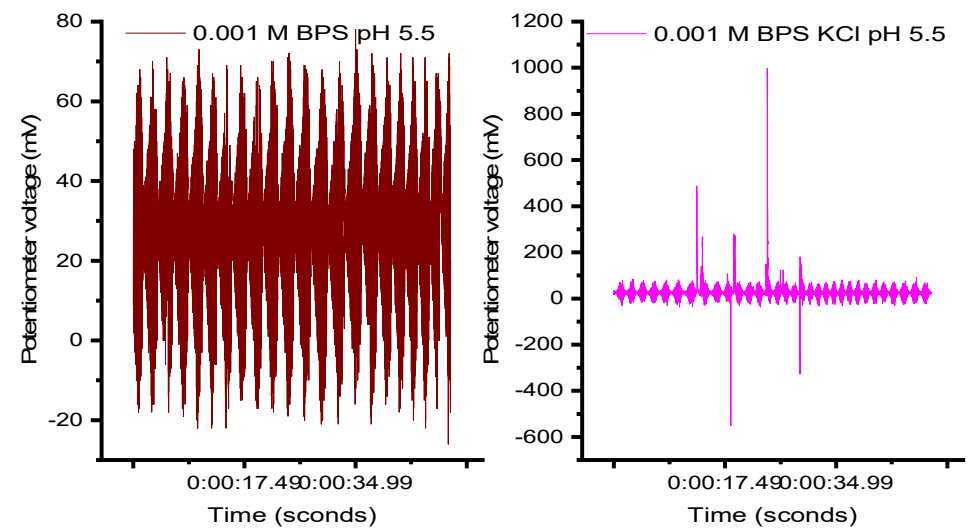

Fig.-1: Voltage Signals (a) PBS 0.001 M, (b) PBS KCl 0.001 M each urea injection with indicator electrodes without immobilization ${ }^{4}$ in 0: 00: 49.94 the total signal voltage of 5,000.
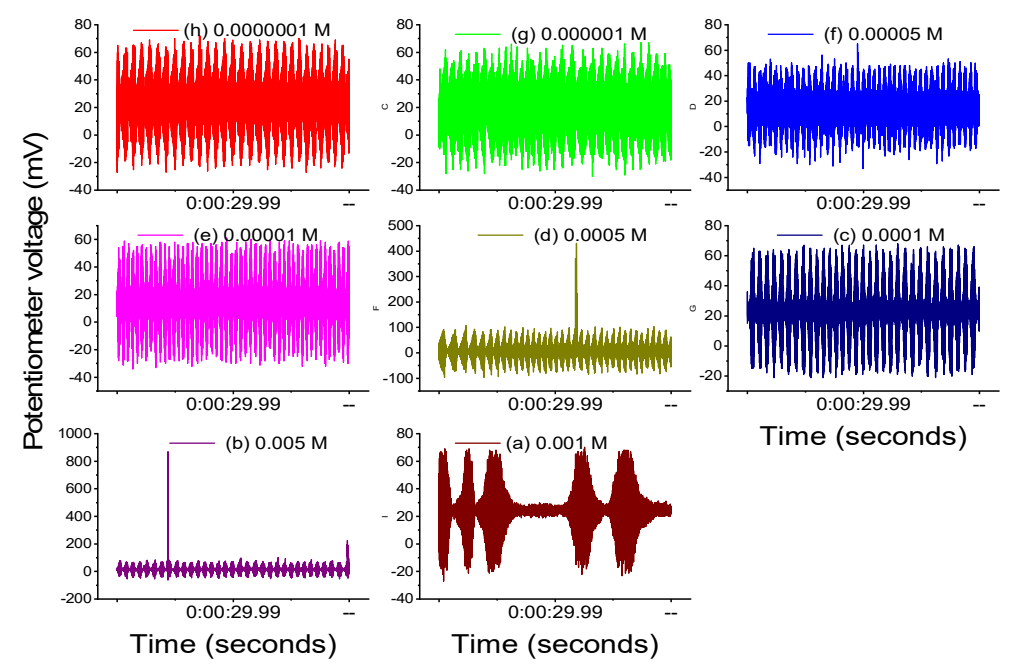

Fig.-2: Response Time of Urea with Electrode Potentiometer Cells without immobilisation in Molarity Variations (a) $0.001 \mathrm{M}$, (b) $0.005 \mathrm{M}$, (c) $0.0001 \mathrm{M}$, (d) $0.0005 \mathrm{M}$, (e) $0.00001 \mathrm{M}$ and (f) $0.00005 \mathrm{M}$, (g) $0.000001 \mathrm{M}$, (h) $0.0000001 \mathrm{M}$ within 0: 00: 59.94 the number of 6,000 Voltage Signals.

The addition of phosphate buffer solution with $\mathrm{KCl} \mathrm{pH} 5.5$ and molarity of $0.001 \mathrm{M}$ changes the potentiometer voltage cycle to an asymmetrical cyclone, as can be seen in Fig.-1 and Fig.-3. Figure-2 is a signal of urea solution at the urea response time with an electrode potentiometer cell without immobilization in variations of molarity (a) $0.001 \mathrm{M}$, (b) $0.005 \mathrm{M}$, (c) $0.0001 \mathrm{M}$, (d) $0.0005 \mathrm{M}$, (e) $0.00001 \mathrm{M}$ and (f) $0.00005 \mathrm{M},(\mathrm{g}) 0.000001 \mathrm{M}$, (h) $0.0000001 \mathrm{M}$. The evolution of electrode potential as a function of time for various concentrations of urea in a solution without buffering ${ }^{5}$, the area that has the best time response is urea $0.001 \mathrm{M}$ and symmetric cell cycle symmetry ${ }^{4}$ The voltage signal profile depends on the charge/discharge time (voltage response to time)can be seen in Figs.-1 to 3. ${ }^{4}$ 
RASĀYAN J. Chem.

Vol. 14 | No. 2 |1356-1368| April - June | 2021
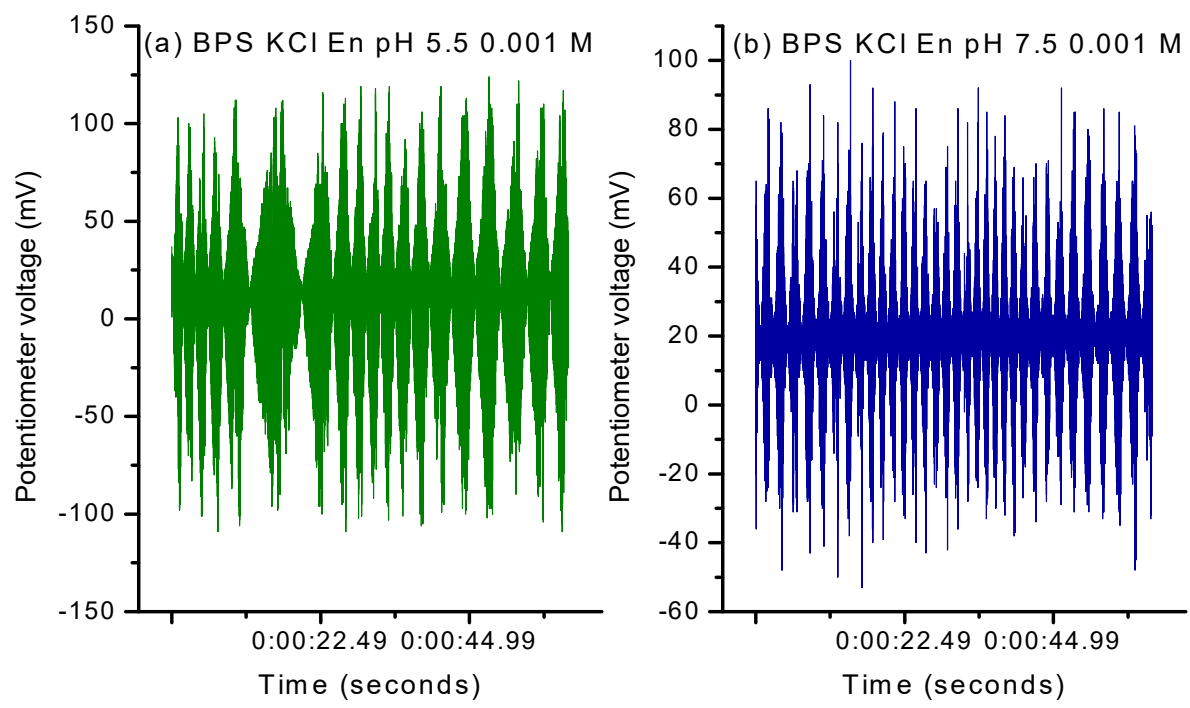

Fig.-3: Voltage Signal (a) (PBS) pH 5.5, (b) (PBS) pH 5.5 plus KCl Enzyme for each Urea Injection with Indicator

Electrodes without immobilization according to ${ }^{4}$ within 0:00: 59.94 number of 6,000 Voltage Signals.
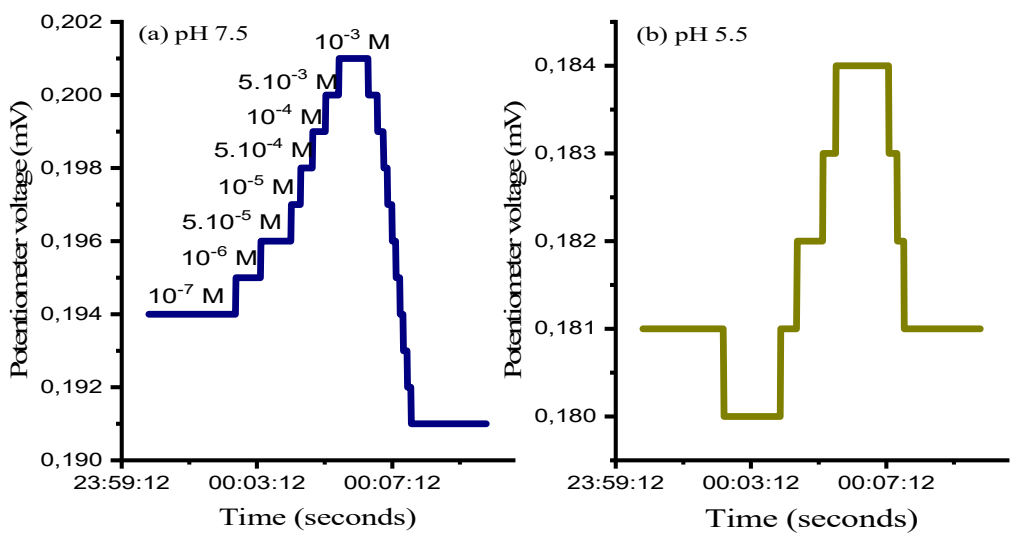

Fig.-4: Potentiometric Response Curves ${ }^{6}$ from Selective Membrane Sensors (a) pH 7.5, (b) pH 5.5 plus $\mathrm{KCl}$ for each Injection of Urea with immobilized enzymes on Indicator Electrodes within 09:59.0 the number of Voltage Signals 6,000 .

The response and reproducibility of the selective membrane urea sensors ${ }^{7}$ at $\mathrm{pH} 7.5$ (a) $\mathrm{pH} 5.5$ (b) from Fig.-4 is better at pH 7.5 can also be seen in Fig.-3(b) voltage signal phosphate buffer solution urea sensor. Response time ${ }^{8}$ active signal of potentiometer cells at $10^{-3} \mathrm{M}$ or $0.001 \mathrm{M}$ molarity with $\mathrm{pH} 7.5$ according to Figure 4, if electrodes are prevented from polarization, electrolytes show ohmic behavior ${ }^{9}$ with a molarity of $10^{-7}-10^{-3} \mathrm{M}$. The action potential is the positive and negative ionic flow that moves in the cell membrane. The formation of polarization can be seen in Figs.- 5 to 7 when the indicator electrode without immobilization is immersed in the potentiometer cell while in Figs. -8 to 12 when the immobilized indicator electrode immersed in the potentiometer cell shows selectively ${ }^{10}$ there are differences in voltage response patterns potentiometer concerning time.

There is a difference in the response of the potentiometer voltage to time images 5-7 with Figs.-8 to 12 on the potentiometric cell when the reference electrode and indicator electrode are immersed in the urea solution as a sensor that analyzes the urea from the print screen display of the computer by the power lab. 
RASĀYAN J. Chem.

Vol. 14 | No. 2 |1356-1368| April - June | 2021

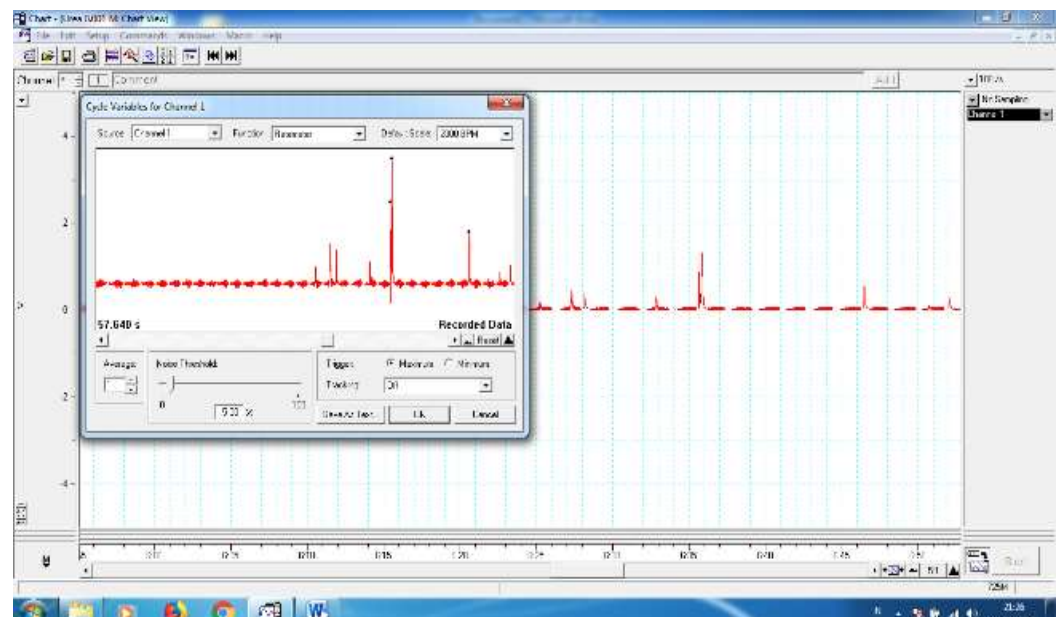

Fig.-5: Voltage Response to Time in a 0.001 M Urea Solution with Indicator Electrodes without immobilization on a 5:1 scale Potentiometer Cell. ${ }^{4}$

The $\mathrm{pH}$ is increasing from the phosphate buffer solution ${ }^{11,12}$ using $0.1 \mathrm{M} \mathrm{NaOH}$ from $\mathrm{pH} 5.5$ to $\mathrm{pH}$ 7.5.

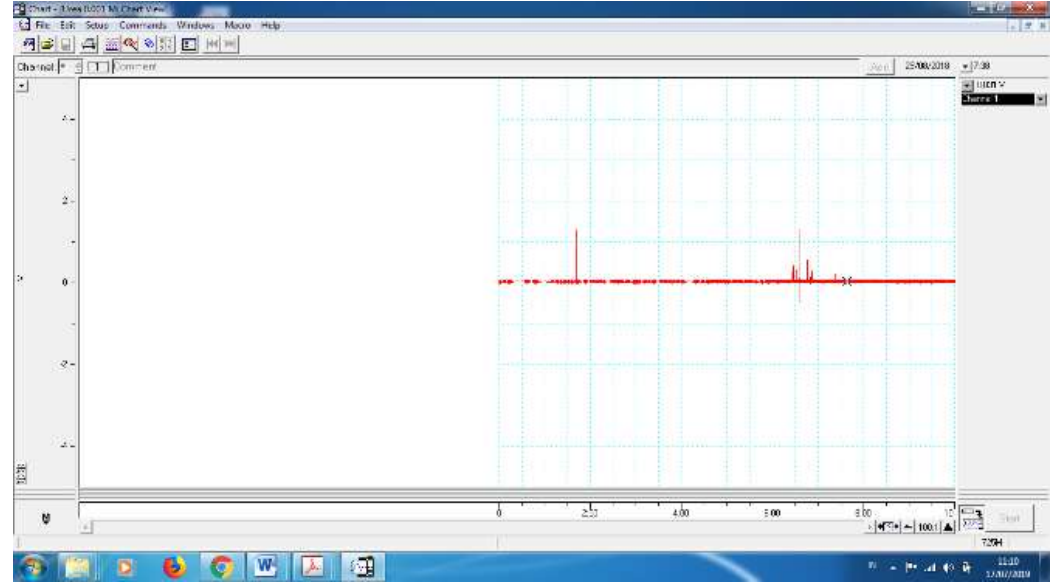

Fig.-6: Voltage Response to time in a 0.001 M Urea Solution with Indicator Electrodes without immobilization on a 100:1 Scale Potentiometer Cell.

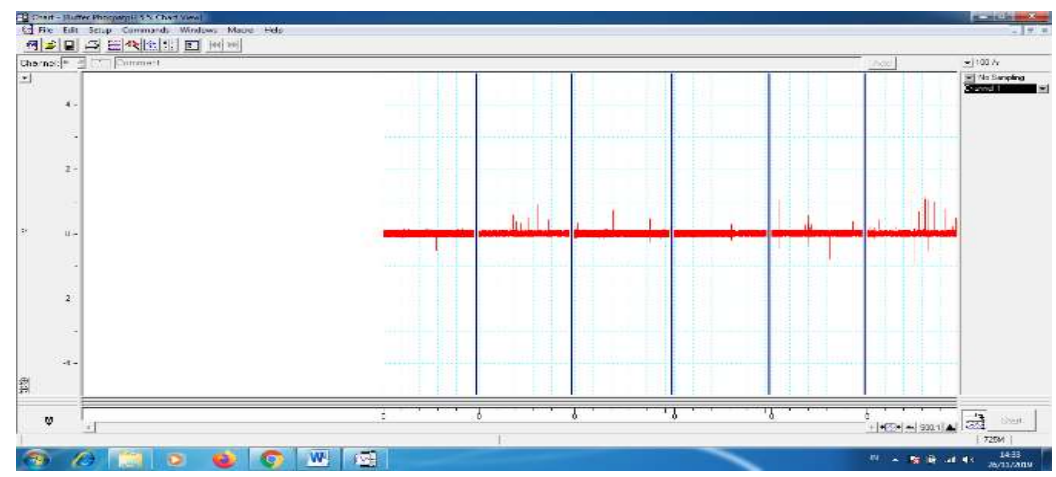

Fig.-7: Voltage Response to Time in a phosphate KCl Buffer Solution of 0.001 M Urea Injection Enzyme with an immobilized Indicator Electrode on a 500:1 Scale Potentiometer Cell.

Potentiometric signals can be measured shown by direct correlation with observations of the activity and oxidation of electroactive compounds that determine cell potential increases in the growth phase is a 
RASĀYAN J. Chem.

Vol. 14 | No. 2 |1356-1368| April - June | 2021

change in cell potential $E_{\text {cel }} l=E_{\text {anode }}-E_{\text {cathode }}{ }^{13}$ can be seen in Figs. $-5,6$ and 7. Figures- 5 to 7 show the voltage to time signal on the potentiometric cell concentration of $0.001 \mathrm{M}$ phosphate buffer (BP) $\mathrm{pH} 7.5$ with reference electrodes and indicator electrodes not immobilized ${ }^{12}$, while Figs. -8 to 12 show the pattern of voltage response to time, where the composition of the electrolyte solution or supporting solution under optimum conditions. The first procedure is to study the urea solution first so that the urea analyte in the best composition gets a higher voltage signal as shown in Figs. -5 and 6; the two buffer solutions were characterized by injection of urea at a molarity of $10^{-7}-10^{-3} \mathrm{M}$ as shown in Fig.-7; all three buffer solutions at the chosen molarity and $\mathrm{pH}$ plus $\mathrm{KCl}$ with molarity variations of $10^{-7}-10^{-3} \mathrm{M}$ are characterized by further urea injection, and the four selected buffer and $\mathrm{KCl}$ solutions plus enzymes were characterized by injection of urea in a molarity variation of $10^{-7}-10^{-3} \mathrm{M}$.

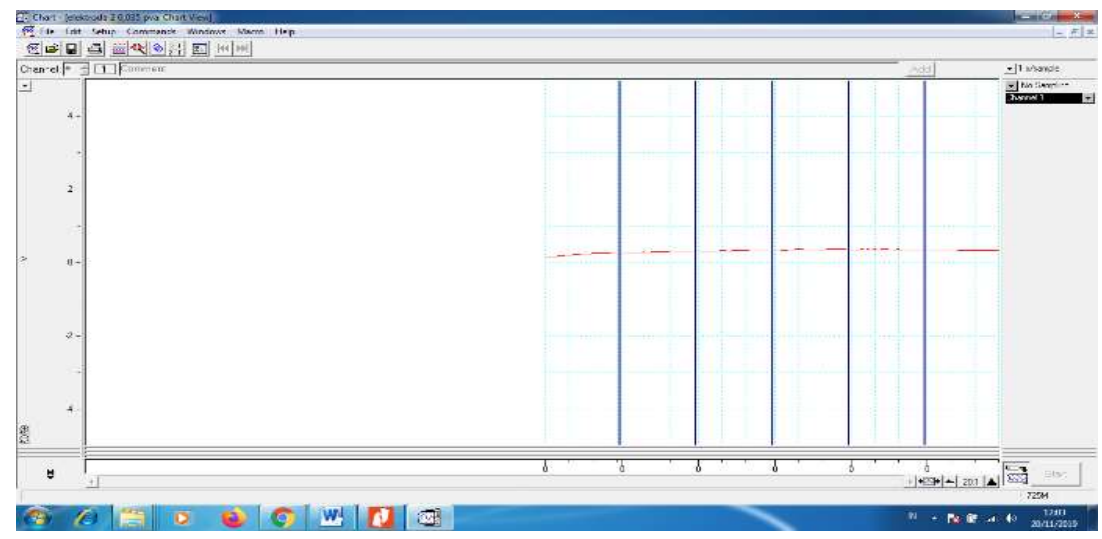

Fig.-8: Voltage Response to Time in a 0.001 M Urea Solution with PVA-enzyme immobilized Indicator Electrodes on a 20:1 Scale Potentiometer Cell.

There is a difference in the display of the potentiometer voltage signal between Figs. -5 to 7 of the nonimmobilized indicator electrode and the Figs. -8 to 12 of the immobilized indicator electrode using a power lab and computer potentiometer the best signal pattern in Fig.-11 that the response time is in the form of plateue $^{12}$, besides that it also takes a long time in the process of urea injection in potentiometric cells.

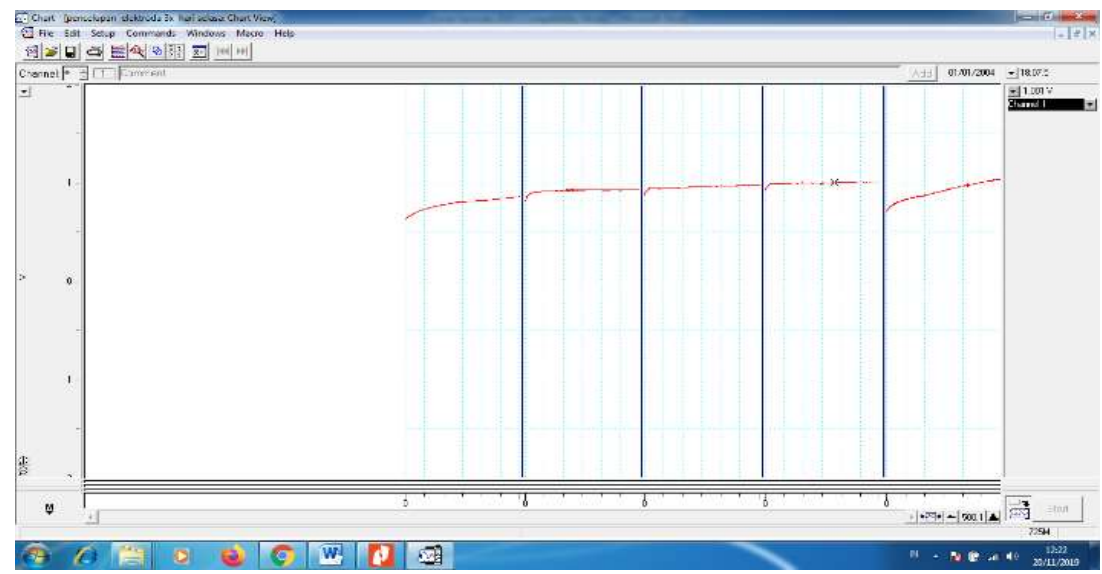

Fig.-9: Voltage Response to Time in a phosphate $\mathrm{KCl}$ Buffer Solution of $0.001 \mathrm{M}$ Urea Injection with a 3x immobilized PVA-enzyme Indicator Electrode on a 500:1 Potentiometer Cell

Optimization of $\mathrm{pH}$ as shown in Fig.-12 of the 2x-immobilized PVC-KTpClPB indicator electrodes in potentiometer cells with $0.001 \mathrm{M}$ phosphate buffer solution $\mathrm{pH} 5.5 \mathrm{KCl}$ urea injection enzyme $0.001 \mathrm{M}$ indicator membrane $2 \mathrm{x}$ dyeing electrode. ${ }^{15}$ The composition of the electrolyte solution used in a potentiometric cell is the same for an immobilized electrode as that which is immobilized using a long 
RASĀYAN J. Chem.

Vol. 14 | No. 2 |1356-1368| April - June | 2021

step. To shorten the determination of the composition of the electrolyte solution, characterization using UV-vis and FTIR was used in addition to the voltage response to the time of the immobilized potentiometer cell as shown in Fig.-13, which is the voltage response to the time of the molarity phosphate buffer urea injection for 11 seconds with indicator electrodes without immobilization on the potentiometer cell. at the molarity of $0.001 \mathrm{M}, 0.005 \mathrm{M}$ and $0.0001 \mathrm{M}$. The procedure still follows the procedures one to four mentioned above.

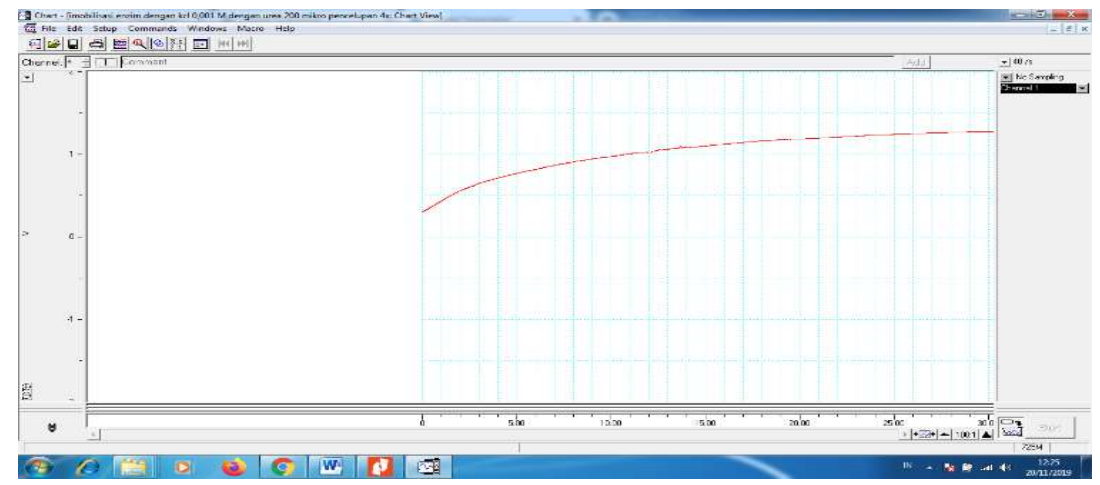

Fig.-10: Voltage Response to Time in a 0.001 M Enzyme-KCl Solution with 3x immobilized PVA-enzyme Indicator Electrodes on a 100:1 Scale Potentiometer Cell.

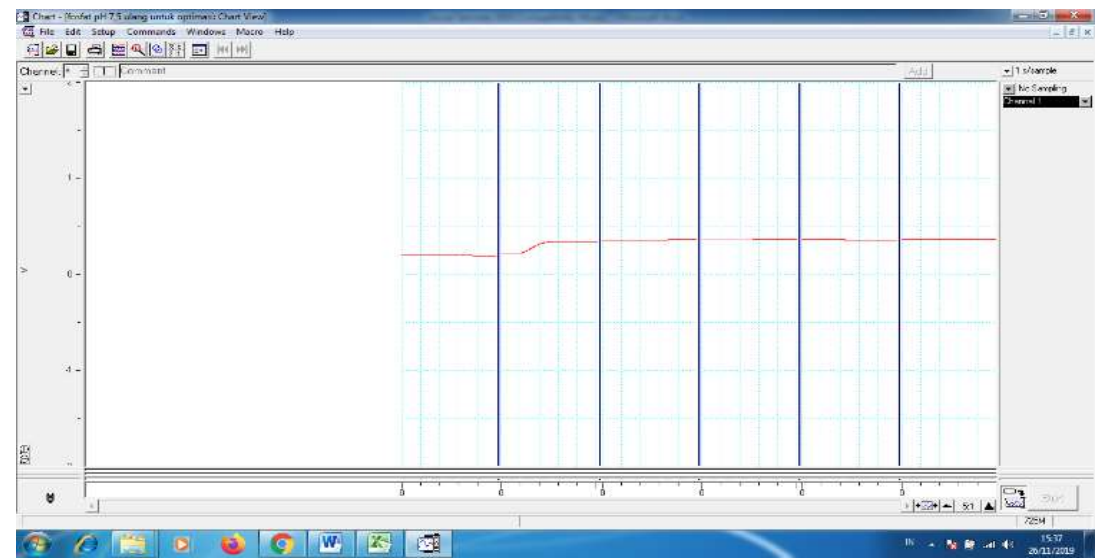

Fig.-11: Voltage Response to Time in a phosphate Buffer Solution 0.001 M pH 7.5 KCl 0.001 M Urea Injection Ezyme with 2x immobilized PVC-KTpCIPB Indicator Electrodes on a 500:1 Scale Potentiometer Cell. ${ }^{14}$

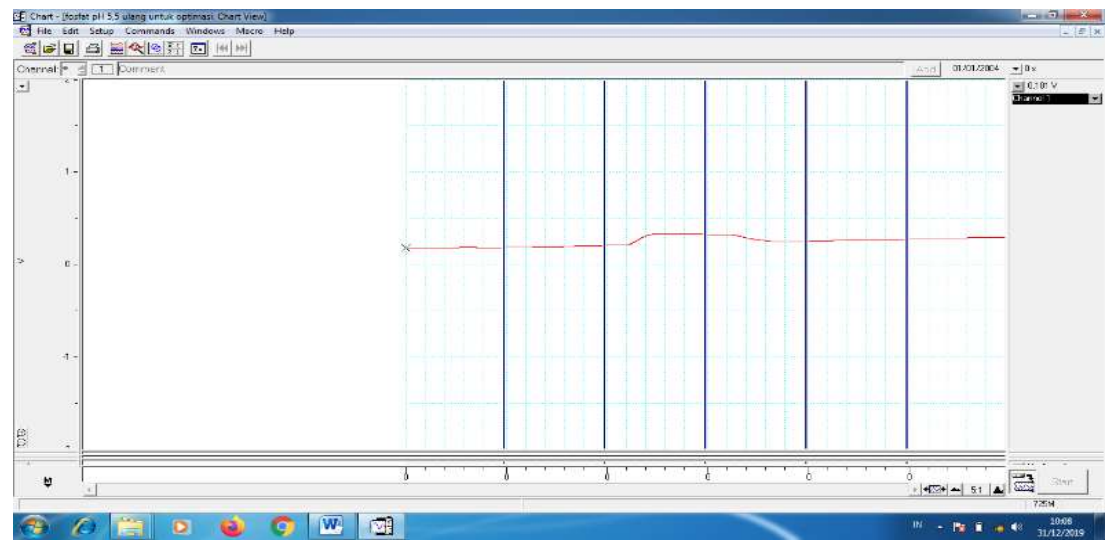

Fig.-12: Voltage Response to Time in a phosphate Buffer Solution 0.001 M pH 5.5 KCl urea Injection Enzyme $0.001 \mathrm{M}$ with a 2x Electrode immobilized PVC-KTpCIPB Indicator on a Potentiometer Cell ${ }^{14}$ with a Scale of 500:1. 
RASĀYAN J. Chem.

Vol. 14 | No. 2 |1356-1368| April - June | 2021

\section{Material and Methods}

\section{EXPERIMENTAL}

The materials used in this study were $\mathrm{KH}_{2} \mathrm{PO}_{4}, \mathrm{KCl}$, urea, and enzymes used in the research were Uriase, EC 3.5.1.5 (Urea) U4002, 50-100 ix type Sigma-Aldrich, as an electrolyte solution from potentiometric cells. The tools used are potentiometric cells consisting of $\mathrm{Ag} / \mathrm{AgCl}$ reference electrodes, immobilized, and immobilized PVA-Enzyme coating PVC-KTpClPB coating electrodes, indicator electrodes derived from tungsten. Potentiometers, Power Labs and computers to view voltage signals as a function of time showing the response of an electrolyte solution. Membrane electrodes ${ }^{16}$ from PVA-KTpCIPB immobilization enzymes from PVA composition analysis: ${ }^{17-19}$ PVA:PVC composition is $1: 1$ with mass $0.0350 \mathrm{~g}$ enzyme $1 \mathrm{mg}$ and KTpClPB $0.0500 \mathrm{~g}$, KTpClPB $0.0700 \mathrm{~g}$, KTpClPB $0.0100 \mathrm{~g}$ KTpClPB $0.0500 \mathrm{~g}$.

\section{General Procedure}

The method used is the biosensor potentiometric method of potentiometric cells through analysis of (1) urea analyte, (2) urea phosphate buffer, (3) $\mathrm{KCl}$ and urea phosphate buffer, (4) $\mathrm{KCl}$ and urea phosphate buffer, (5) $\mathrm{KCl}$ urea phosphate buffer immobilized enzymes with a $\mathrm{pH}$ variation of 5.5 and 7.5 , were analyzed in advance of the $\mathrm{pH}$ buffer phosphate (BP) variation. The following steps (1) - (5) are characterized by spectrum patterns and FTIR functional groups and absorbance and UV-Vis polarization patterns. Urea analyzers were analyzed from the voltage response to time with molarity variations of $0.001 \mathrm{M}, 0.005 \mathrm{M}$ and $0.0005 \mathrm{M}$ for maximum.

\section{Detection Method}

The urea cell analyzer potentiometer sensor analyzer has been analyzed namely $0.001 \mathrm{M}$ phosphate buffer $\mathrm{pH} 7.5$ the best conditions with $\mathrm{KCl} 0.001 \mathrm{M}$ solution and $0.001 \mathrm{M}$ urea as potentiometer cell electrolyte solution ${ }^{12}$.

\section{RESULTS AND DISCUSSION}

After testing the material by characterizing the PVA-enzyme immobilization membrane PVC-KTpCIPB coating, followed by a reversible test ${ }^{12}$ through linear curve characterization with criteria obtained sensitivity is $60 \mathrm{mV} /$ decade using phosphate buffer $\mathrm{KH}_{2} \mathrm{PO}_{4} 0.001 \mathrm{M} \mathrm{pH} 7.5, \mathrm{KCl} 0.001 \mathrm{M}$ injection urea ${ }^{17}$ based on the results of this study continued characterization of electrolyte solutions to see the best response. Retrieval of data begins with the print screen display of the response signal from urea solution ranging from $0.0000001 \mathrm{M}$ to $0.01 \mathrm{M}$, urea injection buffer from $0.0005 \mathrm{M}$ to $0.01 \mathrm{M}$, urea injection buffer and $\mathrm{KCl}$.

The degree of acid solubility ${ }^{13}$ (or the degree of acid dissociation between $\mathrm{pH} 0-7$, even though the $\mathrm{H}^{+}$ concentration is increasing, there is still dissolved $\mathrm{OH}$, for the base the concentration is between $\mathrm{pH} 7$ and $\mathrm{pH}$ 14. The $\mathrm{pKa}$ value is defined as "minus the logarithm of the concentration of $\mathrm{H}^{+}$ions in solution". A phosphate buffer solution $\mathrm{KH}_{2} \mathrm{PO}_{4} 0.001 \mathrm{M} \mathrm{pH} 7.5, \mathrm{KCl} 0.001 \mathrm{M}$ urea injection means the potentiometer cell electrolyte solution is alkaline. ${ }^{12}$

The response time and duration of the electrodes in the range of solution $10^{-5}-10^{-2} \mathrm{~mol} / \mathrm{L}$ for each potentiometric sensor, ${ }^{20}$ the time response curve pattern is in accordance ${ }^{21}$ for images 11 (immobilized indicator electrode) and Fig.-13 (non-immobilized indicator electrode). Potentiometric methods have advantages such as high sensitivity, high selectivity, low cost, and fast determination. To determine the electrode reversibility, the technique was completed in the reverse concentration order, starting with the highest concentration and ending with the lowest concentration. ${ }^{20}$

Observations in electrolytes are evaluated using $\mathrm{Cu} \mid$ cells $\mathrm{Li}$ type coin separator and causes an internal short circuit, which results in safety problems. Highly stable voltage polarization up to 330 hours cycle symmetric cells using electrolytes produces greatly increased voltage polarization and random voltage oscillations. Electrolyte compatibility with various cathodes to cathode material ${ }^{4}$ has been shown Reversible cycle $\operatorname{trends}^{17}$ for electrode indicators of PVA immobilization-PVC-KTpClPB coating enzymes with linear curves have a sensitivity of $19.069 \mathrm{mV} /$ decade meets reversible criteria using a phosphate buffer of $\mathrm{KH}_{2} \mathrm{PO}_{4} 0.001 \mathrm{M} \mathrm{pH}$ 7.5. The $\mathrm{pH}$ value of the phosphate buffer solution can be increased to 7.40 by $\mathrm{HCl}$ and $\mathrm{NaOH}$ solutions, the longest immersion time is 33 weeks. ${ }^{22} \mathrm{~A} 0.05 \mathrm{M}$ 
RASĀYAN J. Chem.

Vol. 14 | No. 2 |1356-1368| April - June | 2021

phosphate buffer $\mathrm{pH} 7.4$ containing $0.1 \mathrm{M} \mathrm{KCl}$, is used as a carrier solution for amperometric measurements. ${ }^{23}$ The effect of phosphate buffer solution concentration on the potentiometric response ${ }^{24}$ can be seen in Fig.-11 after the indicator electrodes were immobilized by PVA-KTpClPB coating enzymes according to membrane composition ${ }^{17}$, if before immobilized as Fig.- 7.

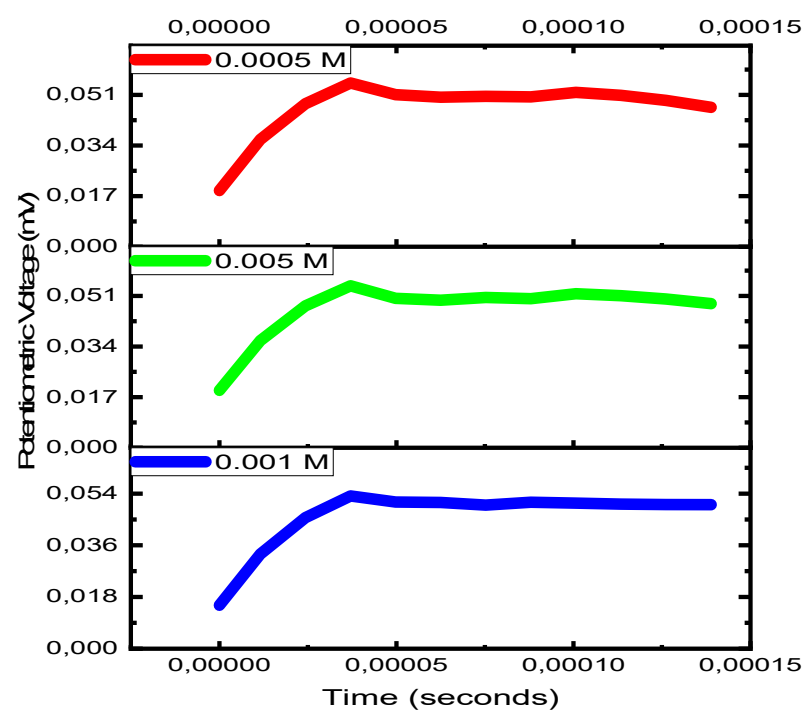

Fig.-13: Response Time of Molarity of Urea Injection phosphate Buffer for 11 seconds Indicator Electrode without immobilization in Potentiometer Cells with a Molarity of (a) $0.001 \mathrm{M}$, (b) $0.005 \mathrm{M}$ and (c) $0.0005 \mathrm{M}$.
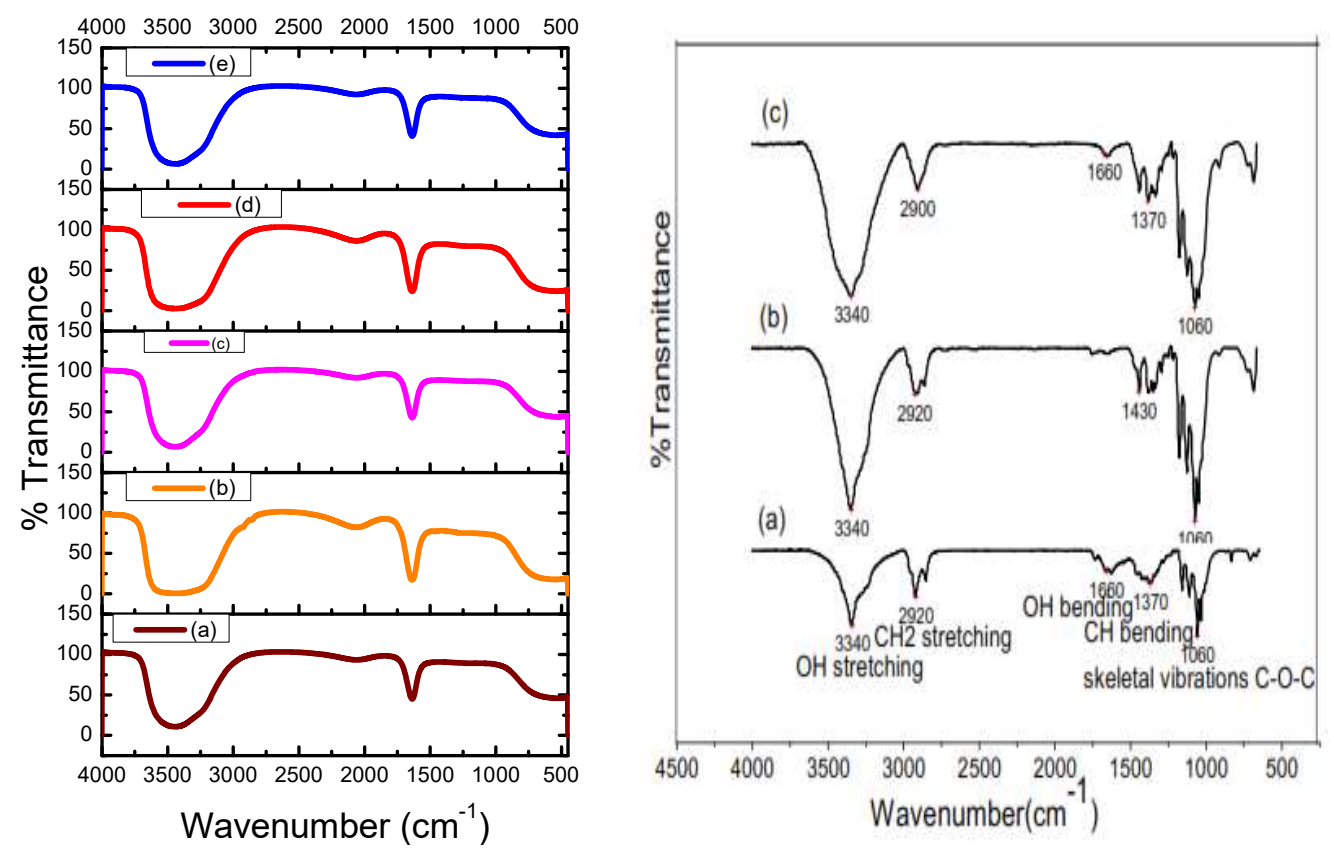

Fig.-14: Spectrum Pattern of FTIR (a) Urea, (b) Buffer pH 5.5 and Urea, (c) Buffer pH $5.5+\mathrm{KCl}$ and Urea, (d) Buffer $\mathrm{pH} 5.5+$ Enzim $+\mathrm{KCl}$ and Urea, (e) Buffer $\mathrm{pH} 7.5+$ Enzim $+\mathrm{KCl}$ and Urea.

Demonstrates linear suitability for buffered solutions with $\mathrm{pH}$ increasing from $\mathrm{pH} 3-11$ for $\mathrm{KCl}$ solutions with increased concentrations from $1 \times 10^{-5} \mathrm{M}-1 \mathrm{M}^{14,25} \mathrm{KCl}$ FTIR spectrum patterns (a) urea, (b) Buffer pH 5.5 and urea, (c) Buffer pH $5.5+\mathrm{KCl}$ and urea, (d) Buffer pH $5.5+$ Enzyme $+\mathrm{KCl}$ and urea, (e) Buffer $\mathrm{pH} 7.5+$ Enzyme $+\mathrm{KCl}$ and urea image 14 left. FTIR buffer pattern phosphate image 14 right part 
RASĀYAN J. Chem.

Vol. 14 | No. 2 |1356-1368| April - June | 2021

there are 2 transmittance spectrum patterns namely (b) and (c) similar to the FTBC pattern of nBC (Nanobacterial cellulose) immersed in phosphate buffer solution ${ }^{22}$ also supported by XRD diffraction spectrum pattern test is also similar. In the FTIR spectrum, the absorption band at $3345 \mathrm{~cm}^{-1}$ stretches for hydroxyl groups and intermolecular hydrogen bonds, stretching vibration absorption bands at 2930 and $2853 \mathrm{~cm}^{-1}$ are each given asymmetric or epoxide $\mathrm{C}-\mathrm{H}$ bonds and intramolecular hydrogen bonds, and vibration absorption bands stretching from 1170 to $1060 \mathrm{~cm}$ is given to the $\mathrm{C}-\mathrm{O}$ bond. ${ }^{11,22}$

\begin{tabular}{|c|c|c|c|c|}
\hline No & Sample & $\begin{array}{l}\text { Research } \\
\text { Frequency } \\
\left(\mathrm{cm}^{-1}\right)\end{array}$ & $\begin{array}{l}\text { Groups Frequency } \\
\qquad\left(\mathrm{cm}^{-1}\right)\end{array}$ & Bonds \\
\hline 1 & (a) & $\begin{array}{l}3435.57 \\
2062.34 \\
1637.28\end{array}$ & $\begin{array}{l}3100-3500 \\
2000-2400 \\
2100-3400 \\
1600-1700 \\
1600-1680 \\
\end{array}$ & $\begin{array}{c}\text { N-H Hydrogen, O-H stretch } \\
\text { C } \equiv \mathrm{C} \\
\text { carboxylic acid O-H } \\
\mathrm{C}=\mathrm{N} \text { stretch } \\
\mathrm{C}=\mathrm{C} \text { Carbon }\end{array}$ \\
\hline 2 & (b) & $\begin{array}{l}3435.26 \\
2065.74 \\
1634.04\end{array}$ & $\begin{array}{l}3100-3500 \\
2000-2400 \\
2100-3400 \\
1600-1700 \\
1600-1680 \\
\end{array}$ & $\begin{array}{c}\text { N-H Hydrogen, O-H stretch } \\
\mathrm{C} \equiv \mathrm{C} \\
\text { carboxylic acid O-H } \\
\mathrm{C}=\mathrm{N} \text { stretch } \\
\mathrm{C}=\mathrm{C} \text { Carbon }\end{array}$ \\
\hline 3 & (c) & $\begin{array}{l}3433.92 \\
2066.68 \\
1637.12\end{array}$ & $\begin{array}{l}3100-3500 \\
2000-2400 \\
2100-3400 \\
1600-1700 \\
1600-1680 \\
\end{array}$ & $\begin{array}{c}\text { N-H Hydrogen, O-H stretch } \\
\mathrm{C} \equiv \mathrm{C} \\
\text { carboxylic acid O-H } \\
\mathrm{C}=\mathrm{N} \text { stretch } \\
\mathrm{C}=\mathrm{C} \text { Carbon }\end{array}$ \\
\hline 4 & (d) & $\begin{array}{l}3435.27 \\
2066.65 \\
1633.66\end{array}$ & $\begin{array}{l}3100-3500 \\
2000-2400 \\
2100-3400 \\
1600-1700 \\
1600-1680 \\
\end{array}$ & $\begin{array}{c}\text { N-H Hydrogen, O-H stretch } \\
\mathrm{C} \equiv \mathrm{C} \\
\text { carboxylic acid O-H } \\
\mathrm{C}=\mathrm{N} \text { stretch } \\
\mathrm{C}=\mathrm{C} \text { Carbon }\end{array}$ \\
\hline 5 & (e) & $\begin{array}{l}3434.90 \\
2064.35 \\
1637.11\end{array}$ & $\begin{array}{l}3100-3500 \\
2000-2400 \\
2100-3400 \\
1600-1700 \\
1600-1680 \\
\end{array}$ & $\begin{array}{c}\text { N-H Hydrogen, O-H stretch } \\
\mathrm{C} \equiv \mathrm{C} \\
\text { carboxylic acid O-H } \\
\mathrm{C}=\mathrm{N} \text { stretch } \\
\mathrm{C}=\mathrm{C} \text { Carbon }\end{array}$ \\
\hline
\end{tabular}

No degradation of the spectrum ${ }^{26}$ only shifts in vibration and changes in spectrum patterns. The concentration of buffer solution can affect the activity of cells that are immobilized in the concentration of phosphate buffer solution. A higher buffer capacity at $20 \mathrm{mM}$ phosphate buffer solution was found to provide a higher correlation coefficient value, where the regression line matches the data in a linear pattern. Higher buffer concentrations can stabilize changes in the $\mathrm{pH}$ of the reaction medium as the system involves enzymatic reactions that release protons..$^{24}$ Initial concentration increases the time for the adsorption process to reach equilibrium in a longer time, high adsorption capacity is taken as the optimal value for further adsorption studies ${ }^{27}$ i.e. $10^{-3} \mathrm{M}$ (Fig.-4).

Effect of $\mathrm{pH}$ and buffer capacity, all biosensor potentiometric cells for the detection of buffer solution concentrations that can influence activity. ${ }^{24}$ The optimization of biosensors is influenced by cell loading carried out on the membrane surface at the electrodes with different concentrations. The buffer capacity is optimized by varying the concentration of the phosphate buffer solution between $1 \mathrm{mM}$ and $50 \mathrm{mM}$. Phosphate buffer solutions at the solution-membrane interface arise because the potassium in the solution selectively diffuses between the aqueous and membrane phases, doped with KTpClB lipophilic salt and ion-selective carriers. ${ }^{28}$ The electrochemical biosensor response uses phosphate buffer $\mathrm{pH}$ 7.5. ${ }^{17,24}$

The interaction mechanism has been examined using (1) electrode membrane solution ${ }^{16}$ from the immobilization of PVA-KTpClPB coting enzymes from the composition analysis of the composition of PVA : PVC composition is $1: 1$ with mass $0.0350 \mathrm{~g}$ enzyme $1 \mathrm{mg}$ and KTpClPB $0.0500 \mathrm{~g} \mathrm{KTpClPB}$, 
RASĀYAN J. Chem.

Vol. 14 | No. 2 |1356-1368| April - June | 2021

$0.0700 \mathrm{~g}$, KTpCIPB $0.0100 \mathrm{~g}$, KTpClPB $0.0500 \mathrm{~g}$, analyzed by transmission spectrum membrane ${ }^{17,18,19}$ with FTIR, (2) Urea solution $0.001 \mathrm{M}$, solution $0.001 \mathrm{M}$ phosphate buffer $\mathrm{pH} 5.5$ urea, phosphate buffer solution $0.001 \mathrm{M} \mathrm{pH} 5.5, \mathrm{KCl} 0.001 \mathrm{M}$ and urea $0.001 \mathrm{M}$, phosphate buffer solution $0.001 \mathrm{M} \mathrm{pH} \mathrm{5.5, \textrm {KCl }}$ $0.001 \mathrm{M}$, enzyme $1 \mathrm{mg}$ and urea $0.001 \mathrm{M}$, analyzed absorbance spectrum and UV-Vis polarization spectrum obtained the greatest absorption and polarization at $\mathrm{pH} 7.5$ molarity of $0.001 \mathrm{M}$ with the greatest polarization $^{29}$ in Fig.-15.

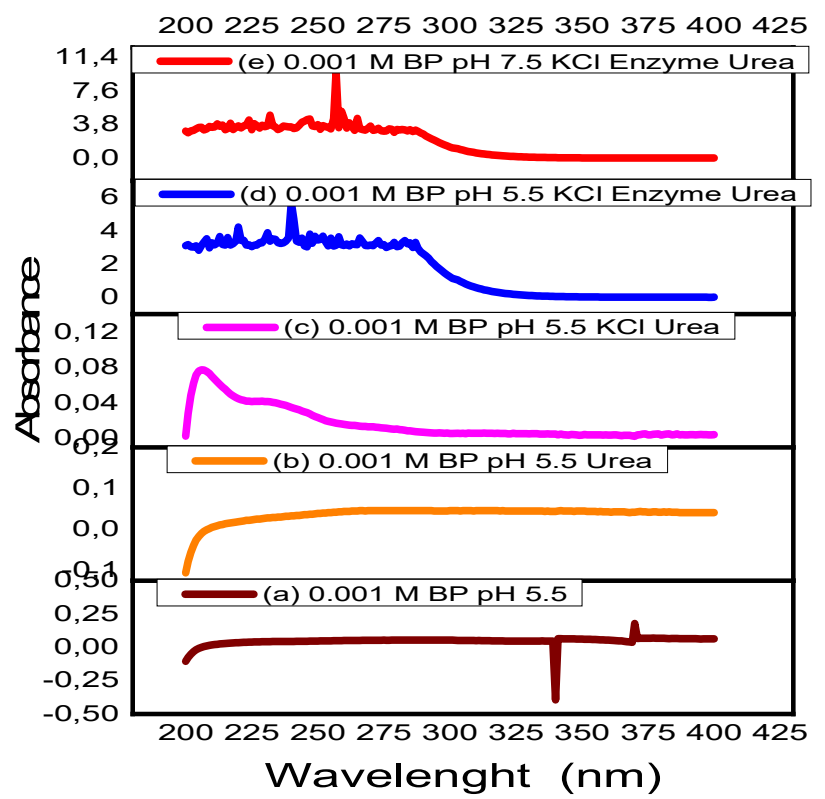

Fig.-15: The UV-Vis Absorbance Spectrum Pattern of Various Solutions (a), (b), (c), (d) and (e), the best at $0.001 \mathrm{M}$ pH 7.5 KCl $0.001 \mathrm{M} 300 \mu \mathrm{L}$ enzyme 1 drop $6 \mathrm{mg} 10 \mathrm{~mL}$ ( 50\% Water and 50\% Alcohol). ${ }^{17}$

According to FTIR analysis, the results of the study of PVA solution and PVC-KTpClPB solution have functional groups from $\mathrm{N}-\mathrm{H}$ in the frequency group $3100-3400 \mathrm{~cm}^{-1}$, O-H in the frequency group $2700-$ $3300 \mathrm{~cm}^{-1}, \mathrm{C}-\mathrm{N}$ in the frequency group $1600-1700 \mathrm{~cm}^{-1}, \mathrm{C}-\mathrm{O}$ in the frequency group $1200-1350 \mathrm{~cm}^{-1}$, $\mathrm{C}-\mathrm{H}$ in the frequency group $700-950 \mathrm{~cm}^{-1}$ and Cis (included in the $\mathrm{C}-\mathrm{H}$ functional group) in the frequency group $650-800 \mathrm{~cm}^{-1}$ are in the PVA solution and PVC coating solution. Unless the functional group $\mathrm{C} \equiv \mathrm{C}$ is only obtained in PVA solutions with a frequency of $2167,106 \mathrm{~cm}^{-1}$ in the frequency group $2100-2200 \mathrm{~cm}^{-1}$. Between the electrolyte solution and the indicator electrode membrane, there is a suitability of the functional groups obtained in the electrolyte solution namely N-H, O-H in the frequency group $3100-3500 \mathrm{~cm}^{-1}, \mathrm{C} \equiv \mathrm{C}$ in the frequency group $2000-2400 \mathrm{~cm}^{-1}, \mathrm{O}-\mathrm{H}$ in the frequency group $2100-3400 \mathrm{~cm}^{-1}$ carboxylic acid, $\mathrm{C}=\mathrm{N}$ in the $1600-1700 \mathrm{~cm}^{-1}$ frequency group, $\mathrm{C}=\mathrm{C}$ in the $1600-$ $1680 \mathrm{~cm}^{-1}$ frequency group from Table-2.

Enzyme activity is calculated by measuring the amount of $\mathrm{NH}_{3}$ ammonia production in which urease can catalyze the hydrolysis of urea as follows: ${ }^{30}$

$$
\mathrm{CO}\left(\mathrm{NH}_{2}\right)_{2}+3 \mathrm{H}_{2} \mathrm{O} \stackrel{\text { Urease }}{\longrightarrow} \mathrm{HCO}_{3}^{-}+2 \mathrm{NH}_{4}^{+}+\mathrm{OH}^{-}
$$

The presence of enzymes in the hydrolysis of urea produces ${ }^{31}$ :

$$
\mathrm{NH}_{2} \mathrm{CONH}_{2}+2 \mathrm{H}_{2} \mathrm{O}+\mathrm{H}^{+} \stackrel{\text { Urease }}{\longrightarrow} \mathrm{HCO}_{3}^{-}+2 \mathrm{NH}_{4}^{+}
$$

Urea produces enzymatic hydrolysis ${ }^{5}$ :

$$
\mathrm{NH}_{2} \mathrm{CONH}_{2}+\mathrm{H}_{2} \mathrm{O} \stackrel{\text { Urease }}{\longrightarrow} \mathrm{CO}_{2}+2 \mathrm{NH}_{3}
$$

Ammonia in the electrode solution becomes balanced with ammonium ions and produces hydroxide ions: ${ }^{32}$

$$
\mathrm{NH}_{3}+\mathrm{H}_{2} \mathrm{O} \rightarrow \mathrm{NH}_{4}^{+}+\mathrm{OH}^{-}
$$


RASĀYAN J. Chem.

Vol. 14 | No. 2 |1356-1368| April - June | 2021

Based on the functional groups, indicator electrode membranes and enzymatic reactions that produce ions with $\mathrm{C}-\mathrm{O}, \mathrm{N}-\mathrm{H}$, and $\mathrm{O}-\mathrm{H}$ functional groups as shown in equations 1 to 4 , whereas in the electrolyte solution no C-O function groups are obtained. absorption spectrum ${ }^{33}$ from the results of FTIR sample tests as shown in Fig.-16.

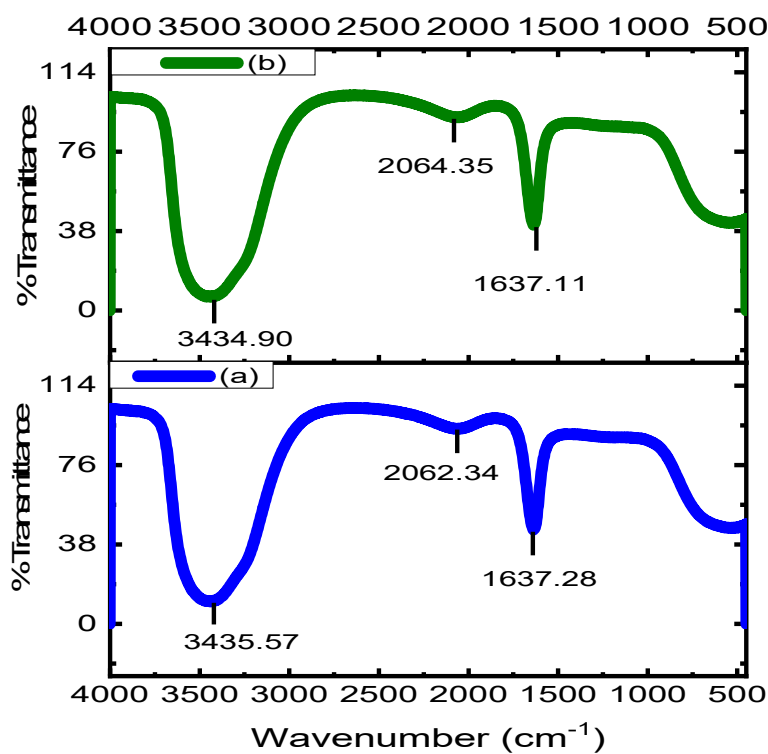

Fig.-16: Pattern Spectrum FTIR (a) Urea, (b) Buffer pH 7.5 + Enzyme $+\mathrm{KCl}$ and Urea

Table-2: Bonding of the Electrolyte Solution Group of Fig.-15

\begin{tabular}{|c|c|c|c|c|}
\hline No & Sample & $\begin{array}{l}\text { Research } \\
\text { Frequency } \\
\left(\mathrm{cm}^{-1}\right)\end{array}$ & $\begin{array}{l}\text { Group Frequency } \\
\left(\mathrm{cm}^{-1}\right)\end{array}$ & Bond \\
\hline 1 & (a) & $\begin{array}{l}3435.57 \\
2062.34 \\
1637.28\end{array}$ & $\begin{array}{l}3100-3500 \\
2000-2400 \\
2100-3400 \\
1600-1700 \\
1600-1680\end{array}$ & $\begin{array}{c}\text { N-H Hydrogen, O-H } \\
\text { stretch } \\
\mathrm{C} \equiv \mathrm{C} \\
\text { carboxylic acid O-H } \\
\mathrm{C}=\mathrm{N} \text { stretch } \\
\mathrm{C}=\mathrm{C} \text { Carbon }\end{array}$ \\
\hline 2 & (b) & $\begin{array}{l}3434.90 \\
2064.35 \\
1637.11\end{array}$ & $\begin{array}{l}3100-3500 \\
2000-2400 \\
2100-3400 \\
1600-1700 \\
1600-1680\end{array}$ & $\begin{array}{c}\text { N-H Hydrogen, O-H } \\
\text { stretch } \\
\mathrm{C} \equiv \mathrm{C} \\
\text { carboxylic acid O-H } \\
\mathrm{C}=\mathrm{N} \text { stretch } \\
\mathrm{C}=\mathrm{C} \text { Carbon }\end{array}$ \\
\hline
\end{tabular}

FTIR spectrum patterns (a) urea, (b) Phosphate buffer pH 7.5 + Enzyme $+\mathrm{KCl}$ and urea in Fig.-16 are similar to only a vibrational shift between urea and phosphate buffer solution $\mathrm{pH} 7.5+$ Enzyme $+\mathrm{KCl}$ can be seen in Table-2. Frequency difference ${ }^{34}$ in Table-1 between sample (a) and sample (c) producing a sample (e) phosphate buffer $\mathrm{pH} 7.5+$ enzyme $+\mathrm{KCl}$ and urea, which is supported by (1) response time of molarity of the phosphate urea injection buffer Fig.-13, (2) UV-Vis Absorption of phosphate buffer 0.001 $\mathrm{M} \mathrm{pH} 7.5 \mathrm{KCl} 0.001 \mathrm{M} 300 \mu \mathrm{L}$ enzyme 1 drop $6 \mathrm{mg} 10 \mathrm{~mL}$ (50\% water and 50\% alcohol) Figure 15. This causes the computer screen display to display the response time of the potentiometer cell between the indicator electrodes without immobilization (unclear Figs.-5 to 7 less selective and sensitive) and immobilized (clear Figs.-8 to12 selective and sensitive) immersed in a $\mathrm{KCl}$ phosphate buffer solution of the enzyme and urea.

\section{CONCLUSION}

The display of a computer print screen for photometer cells with indicator electrodes being immobilized with a PVA membrane-PVC-KTpClPB coating enzymes closely matches the appearance of the response 
RASĀYAN J. Chem.

Vol. 14 | No. 2 |1356-1368| April - June | 2021

time characteristics with note composition of the PVA electrode membrane:PVC is $1: 1$, and PVC:KTpClPB 1:2 with $1 \%$ enzyme and enzyme $\mathrm{KCl}$ phosphate buffer solution, and urea $0.001 \mathrm{M} \mathrm{pH}$ 7.5. The method of optimizing the electrolyte solution with the potentiometric method, the long process can be shortened by characterizing the electrolyte solution using UV-Vis and FTIR characters first.

\section{ACKNOWLEDGEMENT}

This research is further research from my dissertation. Thanks, are also given to Prof. Timbangen Sembiring, as a Promoter and Dr. Kerista Tarigan as Co-promoter at Universitas Sumatera Utara and Prof. Manohar Situmorang as Co-promoter at Universitas Negeri Medan in developing further research relating to urea sensor with immobilization techniques.

\section{REFERENCES}

1. A. Basile, A. I. Bhatt and A.P. O’Mullane, Nature Communications, 7, ncomms11794 (2016), DOI: $10.1038 /$ ncomms 11794

2. M. S. N. Z. Hausmann, Ph. D. Thesis, Faculty of Saint Louis University, Madrid, Spain (2014)

3. E. Kim, Y. Liu and G. F. Payne, Biomimetics, 2(3), 11(2017), DOI:10.3390/biomimetics2030011

4. R. Miao, J. Yang, Z. Xu, J. Wang, Y. Nuli and L. Sun, Scientific Reports, 6, 21771(2016), DOI: $10.1038 /$ srep21771

5. C-Y. Lai, P. J. S. Foot, J. W. Brown and P. Spearman, Biosensors, 7(1), 13(2017), DOI: $10.3390 /$ bios 7010013

6. N. S. Abdalla, M. A. Youssef, H. Algarni, N. S. Awwad and A. H. Kamel, Molecules, 24(4), 712(2019), DOI:10.3390/molecules24040712

7. O. Isildak, F. Saymaz, A. Karadag, N. O. Korkmaz and A. Attar, BioMed Research International, Vol. 2014, Article ID 251653(2014), DOI:10.1155/2014/251653

8. K. I. Papadimitriou, C. Wang, M. L. Rogers, Sally A. N. Gowers, C. L. Leong, M. G. Boutelle and E. M. Drakakis, Frontiers in Human Neuroscience, 10, 212 (2016), DOI:10.3389/fnhum.2016.00212

9. Y. Wang, H. Xu, J. Zhang and G. Li, Sensors, 8(4), 2043(2008), DOI:10.3390/s8042043

10. C. Bieg, K. Fuchsberger and M. Stelzle, Analytical and Bioanalytical Chemistry, 409, 45(2017), DOI: $10.1007 / \mathrm{s} 00216-016-9945-6$

11. D. H. Cho, E. Y. Kim, K. H. Chu, World Journal of Microbiology and Biotechnology, 27, 1911 (2011), DOI:10.1007/s11274-011-0652-3

12. A. Hakim S, In Proceedings of Seminar Nasional SAINS, TEKNOLOGI, HUMANIORA DAN PENDIDIKAN 2018 (E-Journal), Universitas Quality, Medan, Indonesia, Volume I, November 2018,

13. M. F. Favre, D. Carrard, R. D. and F. Fischer, Journal of Industrial Microbiology and Biotechnology, 36(10), 1307(2009), DOI:10.1007/s10295-009-0614-Z

14. J. Wang, C. Wu, N. Hu, J. Zhou, L. Du and P. Wang, Biosensors, 2, 2(2012), DOI: $10.3390 /$ bios 2020127

15. N. A. Alarfaj and M. F. El-Tohamy, International Journal of Molecular Science, 17(12), 2027(2016), DOI: $10.3390 /$ ijms 17122027

16. A. Hakim S, T. Sembiring, K. Sebayang, M. Situmorang, K. Tarigan, K. Sembiring, S. Mihardi, E. N. Waruwu, Journal of Physics: Conference Series, 1816, 012088(2021), DOI:10.1088/1742$6596 / 1816 / 1 / 012088$

17. A. Hakim S, T. Sembiring, K. Tarigan, K. Sebayang, M. Situmorang and N. M. Noer, Rasayan Journal of Chemistry, 12(2), 780(2019), DOI:10.31788/RJC.2019.1225143

18. A. Hakim S, K. Tarigan, M. Situmorang and T. Sembiring, Journal of Physics: Conference Series, 1317, 012042(2019), DOI:10.1088/1742-6596/1317/1/012042

19. A. Hakim S, K. Tarigan, M. Situmorang, T. Sembiring and F. S. Ritonga, In Proceedings of AISTSSE 2018, October 18-19, Medan, Indonesia, 2019 EAI, pp. 1-7 (2019), DOI:10.4108/eai.18-102018.2287326

20. R. F. Aglan, M. M. Hamed and H. M. Saleh, Journal of Analytical Science and Technology, 10, 7 (2019), DOI: 10.1186/s40543-019-0166-4

21. A. Khan, A. A. P. Khan, A. M. Asiri and M. A. Rub, PLoS ONE, 9, 5(2014), 
RASĀYAN J. Chem.

Vol. 14 | No. 2 |1356-1368| April - June | 2021

DOI:10.1371/journal.pone.0096897

22. Y. Chen, T. Xi, Y. Zheng, L. Zhou and Y. Wan, Journal of Biomimetics, Biomaterials and Tissue Engineering, 10, 55(2011), DOI:10.4028/www.scientific.net/JBBTE.10.55

23. F. Arduini, D. Neagu, V. Scognamiglio, S. Patarino, D. Moscone and G. Palleschi, Chemosensors, 3(2), 129(2015), DOI:10.3390/chemosensors3020129

24. S. S. M. Hassan, S. M. Abdelbasir, M. A. Fathy, A. E. E. Amr, M. A. Al-Omar and A. H. Kamel, Nanomaterials, 9(8), 1160(2019), DOI:10.3390/nano9081160

25. M. J. Mason, A. K. Simpson, M. P. Mahaut-Smith and H. P. C. Robinson, Biophysical Journal, 88(1), 739(2005), DOI:10.1529/biophysj.104.049866

26. H. Saroyan, G. Z. Kyzas and E. A. Deliyanni, Processes, 7(1), 40 (2019), DOI:10.3390/pr7010040

27. Y. Wu, S. Feng, B. Li, X. Mi, World Journal of Microbiology and Biotechnology, 26, 249(2010), DOI:10.1007/s11274-009-0167-3

28. R. Rosenberg, M. S. B. Jr., S. Braganza, C. Vaishnav, R. Karnik and A. J. Hart, PLoS ONE,13(9), e0203862(2018), DOI:10.1371/journal.pone.0203862

29. C. Molardi, T. Paixão, A. Beisenova, R. Min, P. Antunes, C. Marques, W. Blanc and D. Tosi, Applied Science, 9(15), $3107(2019)$, DOI:10.3390/app9153107

30. C. Lue, T. Yu, C. Yang, D. G. Pijanowska and C. Lai, Sensors, 11(5), 4562(2011), DOI: $10.3390 / \mathrm{s} 110504562$

31. E. Jaworska, K. Maksymiuk and A. Michalska, Chemosensors, 3(3), 200(2015), DOI: $10.3390 /$ chemosensors3030200

32. R. Sharma, Y. S Rajput, S. Kaur and S. K. Tomar, Journal of Dairy Research, 75(4), 466(2008), DOI: $10.1017 / \mathrm{S} 0022029908003488$

33. J. Kumirska, M. Czerwicka, Z. Kaczynski, A. Bychowska, K. Brzozowski, J. Thöming and P. Stepnowski, Marine Drugs, 8(5), 1567(2010), DOI:10.3390/md8051567

34. Y. Wu, X. Du, R. Gao, J. Li, W. Li, H. Yu, Z. Jiang, Z. Wang and H. Tai, Nanoscale Research Letters, 14, 72(2019), DOI: 10.1186/s11671-019-2906-1

[RJC-6103/2020] 